\title{
ISOLATION AND FRACTIONATION OF HUMIC SUBSTANCES PRESENT IN WATER WITH THE USE OF ANION-EXCHANGE RESINS AND ULTRAFILTRATION
}

\author{
A. Urbanowska ${ }^{1 *}$ and M. Kabsch-Korbutowicz ${ }^{1}$ \\ ${ }^{1}$ Wroclaw University of Science and Technology, Faculty of Environmental Engineering, Chair in Water and Wastewater Treatment \\ Technology, Wybrzeze Wyspianskiego 27, 50-370 Wroclaw, Poland.
}

(Submitted: October 11, 2017 ; Revised: November 11, 2017 ; Accepted: December 11, 2017)

\begin{abstract}
Natural water treatment requires emphasis on humic substances (HS) removal because of disinfection by-product formation possibilities. Thus, detailed research on HS structure and properties is necessary. Two model solutions of different origin were used in this study. A100, A200, A400, A870 and DEAE-cellulose anion exchange resins were used for the one-stage isolation of HS. Model solutions and eluates from the respective resins were subjected to filtration using regenerated cellulose 1, 5 and $10 \mathrm{kDa}$ MWCO ultrafiltration membranes. The results allowed ranking of analyzed anionites according to the isolation capacity of HS: DEAE $>$ A $870>$ A100 $>$ A400 $>$ A200. Analysis of the HS molecular size distribution shows that hydrophilic compounds of low molecular weight (MW) are dominant in natural water, whereas in the Aldrich humic acid solution and in the eluates after each resin, large MW hydrophobic compounds are predominant.

Keywords: Humic substances; Ion exchange resins; Ultrafiltration; Fractionation.
\end{abstract}

\section{INTRODUCTION}

Natural raw water sources for the technological systems of water treatment plants contain numerous organic and inorganic constituents (Sillanpää, 2014). The main group of natural organic matter (NOM) present in raw water sources are dissolved humic substances (HS) (Baalousha et al., 2008). Their presence in the water is quite troublesome for many reasons, e.g., they are responsible for water taste, smell and, most importantly, they act as precursors of disinfection by-products (Grefte et al., 2013; Krupińska et al., 2013; Rajca, 2015). Disinfection by-products are a product of the oxidation of organic compounds with the use of chlorine or ozone, leading to the formation of carcinogenic chlorine-derived organic compounds and non-fully oxidized organic compounds, respectively (Bond et al., 2014; Tubić et al., 2013).
Humic substances are high molecular weight, complex, heterogeneous acidic polymers of yellow or brown colour (Nieder and Benbi, 2008). They emerge in microbiological reactions resulting from the decomposition of dead plant and animal tissues (Sutzkover-Gutman et al., 2010). The composition of the resulting mixture is strongly dependent on the environmental conditions and the age of the material from which it was formed (Metsämuuronen, 2014). In spite of years of extensive research on humic substances, their chemical structure has not been clearly defined (Wershaw et al., 1998). It was also impossible to specify all the properties of these compounds. Due to diversity and variability, only the general principles of their structure and the elementary composition have been described. It is known that humic substances are very slowly biodegradable and are poorly soluble or insoluble in water. They are usually categorized

\footnotetext{
*Urbanowska Agnieszka, agnieszka.urbanowska@pwr.edu.pl
} 
by differences in solubility in aqueous solutions into humic acids, fulvic acids and humins (Malaisamy et al., 2011). The share of particular groups varies depending on the conditions of the humification process (Tan, 2014). Conducting comprehensive research on the structure and properties of humus substances requires their isolatation from the water matrix. The complete isolation process consists of 3 stages: concentration, purification and fractionation.

The acidic nature of aqueous humic substances is utilized in the single stage isolation of these compounds with the use of anion-exchange resins. Hydrophilic resins of high porosity are suitable for this purpose, where higher porosity generally results in an increased dissolved humic substances adsorption efficiency (Bolto et al., 2002b; Cornelissen et al., 2008). One of the resins of this type is DEAEcellulose (diethylaminoethyl cellulose). It is a weak base anion exchanger with a hydrophilic skeleton and tertiary amine functional groups (Maeng et al., 2015). Application of DEAE enables almost total isolation of organic acids without $\mathrm{pH}$ correction, which allows for the most qualitative and quantitative representation of humic fractions (Lam and Simpson, 2006). Despite the relatively high yields of the process (60 - 90\%) (Boyer et al., 2008), the adsorption of humic substances on anion exchange resins is a method used primarily in water purification technology (Pruss and Pruss, 2016). As a method used to isolate humus substances, it is used rather infrequently.

Isolation and fractionation of aqueous humic substances is also possible using membrane processes. In this method, molecular weight is the decisive factor for determining the presence of humic substances in a particular fraction. The selection of membranes for fractionation is based on the effectiveness of the retention of specific molecular weights. The most commonly used membrane techniques are nanofiltration (NF) and ultrafiltration (UF).

Nanofiltration membranes effectively separate molecules of MW > 200-300 Da. Moreover, they are characterized by a specific ion selectivity - they easily pass monovalent ions (up to 60\%) (Malaisamy et al., 2011), while retaining polyvalent ions (about 85 - 95\%) (Honokis et al., 2011). Unfortunately, as the amount of humic substances in the concentrate increases, the amount of di- and trivalent ions also increases, which makes it difficult to carry out detailed research. In this case, an additional purification step for the isolated organic matter should be carried out.
The ultrafiltration process allows the concentration of 0.005-0.1 $\mu \mathrm{m}$ particles.

Membrane techniques are a group of separation methods that are constantly evolving. They are increasingly used in water treatment as a means of effective removal of humic substances. Unfortunately, their use in the isolation of aqueous humic substances is still limited due to the lack of sufficient membrane selectivity. However, these techniques can be used successfully for the initial concentration and fractionation of aqueous humic substances (Zazouli et al., 2008).

Considering the above, an effort has been undertaken to isolate aqueous humic substances with 5 anion-exchange resins and fractionate them using 3 ultrafiltration membranes.

\section{MATERIALS AND METHODS}

Studies on the isolation and fractionation of aqueous humic substances were carried out for two model solutions with a similar concentration of organic matter. The organic matter was obtained by either mixing tap water and the water taken from a stream flowing from the Batorowski Peat Bog in the Table Mountains (Poland, coordinates: 50²7'29.97' N, $16^{\circ} 23^{\prime} 16.87$ 'E) (model solution 1), or by dissolving humic acid (Aldrich) in tap water at a concentration of $10 \mathrm{~g} / \mathrm{m}^{3}$ (model solution 2). Tap water was used to adjust sample color intensities to equal value in order to minimize initial NOM concentration on results. The content of humic substances in the solutions was determined by measuring the color intensity (UV 350 nm absorbance), UV $254 \mathrm{~nm}$ absorbance (both on a Shimadzu UV1240 spectrophotometer) and dissolved organic carbon (DOC) concentration (Shimadzu TOC 5050). The DOC concentration measurement is the most reliable method for determining the total amount of humic substances, while the color of water indicates the presence of macromolecular fractions. UV absorbance at $254 \mathrm{~nm}$ denotes the fraction of humic substances containing aromatic structures. The properties of the test solutions are shown in Table 1.

Five anion exchange resins: A100, A200, A400, A870 and DEAE-Cellulose were used for the single stage isolation of aqueous humic substances. According to the manufacturers recommendations, the initial preparation of A100, A200, A400 and A870 resins included each resin being converted to their

Table 1. Properties of test solutions.

\begin{tabular}{|c|c|c|c|c|c|}
\hline & Solution & $\begin{array}{l}\text { Colour } \\
\text { g Pt } \cdot \mathbf{m}^{-3}\end{array}$ & $\begin{array}{c}\text { UV } 254 \mathrm{~nm} \\
\text { absorbance } \\
\mathrm{m}^{-1}\end{array}$ & $\begin{array}{c}\text { DOC } \\
\text { g C } \cdot \mathbf{m}^{-3}\end{array}$ & $\begin{array}{c}\text { Conductivity } \\
\mathrm{mS} / \mathrm{m}\end{array}$ \\
\hline Model solution 1 & peat bog water + tap water & 51.24 & 33.8 & 10.51 & 321 \\
\hline Model solution 2 & humic acid + tap water & 51.70 & 24.2 & 8.11 & 690 \\
\hline
\end{tabular}


Table 2. Characteristics of ion exchange resins (Purolite, Santa Cruz Biotechnology).

\begin{tabular}{|c|c|c|c|c|c|c|}
\hline Name & Type & $\begin{array}{l}\text { Polymer } \\
\text { structure }\end{array}$ & Function groups & $\begin{array}{c}\text { Ion exchange } \\
\text { capacity, } \\
\text { val } / \mathbf{d m}^{3} \\
\end{array}$ & $\begin{array}{c}\text { Moisture } \\
\text { retention, } \\
\% \\
\end{array}$ & $\begin{array}{c}\text { Particle } \\
\text { size, } \\
\mu \mathrm{m} \\
\end{array}$ \\
\hline Purolite A100 & weak base & $\begin{array}{l}\text { polystyrene } \\
\text { macroporous }\end{array}$ & $\mathrm{R}-\mathrm{N}\left(\mathrm{CH}_{3}\right)_{2}$ & 1.3 & $53-60$ & $300-1200$ \\
\hline Purolite A200 & strong base type II & gel polystyrene & $\mathrm{R}\left(\mathrm{CH}_{3}\right)_{2}\left(\mathrm{C}_{2} \mathrm{H}_{4} \mathrm{OH}\right) \mathrm{N}^{+}$ & 1.3 & $45-51$ & $300-1200$ \\
\hline Purolite A400 & strong base type I & gel polystyrene & $\mathrm{R}-\mathrm{N}^{+}\left(\mathrm{CH}_{3}\right)_{3}$ & 1.3 & $48-54$ & $300-1200$ \\
\hline Purolite A870 & $\begin{array}{l}\text { mixed weak base / } \\
\text { strong base }\end{array}$ & gel polyacrylic & $\mathrm{R}-\mathrm{N}\left(\mathrm{CH}_{3}\right)_{2}, \mathrm{R}-\mathrm{N}^{+}\left(\mathrm{CH}_{3}\right)_{3}$ & 1.25 & $56-62$ & $300-1200$ \\
\hline DEAE-Cellulose & weak base & - & $\mathrm{R}-\mathrm{OC}_{2} \mathrm{H}_{4} \mathrm{~N}\left(\mathrm{C}_{2} \mathrm{H}_{5}\right)_{2}$ & $0.87-1$ & $70-76$ & $100-200$ \\
\hline
\end{tabular}

chloride form by placing them in $12 \% \mathrm{NaCl}$ solution and then rinsing them in redistilled water until the brine is completely removed. On the other hand, the DEAECellulose resin manufacturer recommended that the initial preparation should consist of mixing in $0.5 \mathrm{M}$ $\mathrm{HCl}$ for $1 \mathrm{~h}$, rinsing with deionized water until $\mathrm{pH} 7$, then immersing in $0.5 \mathrm{M} \mathrm{NaOH}$ for $1 \mathrm{~h}$ and rinsing again until $\mathrm{pH} 7$ is achieved. The characteristics of the examined anion exchange resins are shown in Table 2.

Isolation of aqueous humic substances was carried out in glass columns (height: $20 \mathrm{~cm}$, internal diameter: $15 \mathrm{~cm}$ ) containing $11 \mathrm{~cm}^{3}$ of the examined resin. 1000 $\mathrm{cm}^{3}$ of a new raw water sample was subjected to adsorption for each resin. The flow rate of the solution through the anion exchange bed was $2 \mathrm{~cm}^{3} / \mathrm{min}$. The elution procedure for each resin included rinsing each column with 2 bed volumes of distilled water followed by $1000 \mathrm{~cm}^{3}$ of $0.1 \mathrm{M} \mathrm{NaOH}$ solution at $5 \mathrm{~cm}^{3} / \mathrm{min}$.

The model solutions (prefiltered through 0.45 $\mu \mathrm{m}$ filters) and resin eluates were tested for the determination of molecular weight distribution by ultrafiltration with the use of membranes made from regenerated cellulose with a $1 \mathrm{kDa}, 5 \mathrm{kDa}$ and $10 \mathrm{kDa}$ MWCO (Table 3).

The molecular mass fractionation scheme for humic substances is shown in Figure 1.

Molecular weight distribution was determined by analyzing the dissolved organic carbon in each membrane permeate, which allowed the percentage share of molecular weight fractions to be determined:

Table 3. Characteristics of membranes used for the determination of NOM molecular weight distribution (Microdyn Nadir).

\begin{tabular}{|c|c|c|c|c|}
\hline $\begin{array}{c}\text { Membrane } \\
\text { type }\end{array}$ & $\begin{array}{c}\text { Membrane } \\
\text { material }\end{array}$ & $\begin{array}{c}\text { MWCO, } \\
\text { kDa }\end{array}$ & $\begin{array}{c}\text { Max temp., } \\
{ }^{\circ} \mathrm{C}\end{array}$ & $\begin{array}{c}\mathrm{pH} \\
\text { range }\end{array}$ \\
\hline $\begin{array}{ll}\text { C } 1 & \\
\text { C } 5 & \text { UF } \\
\text { C } 10 & \end{array}$ & $\begin{array}{l}\text { regenerated } \\
\text { cellulose }\end{array}$ & $\begin{array}{c}1 \\
5 \\
10\end{array}$ & 55 & $1-11$ \\
\hline
\end{tabular}

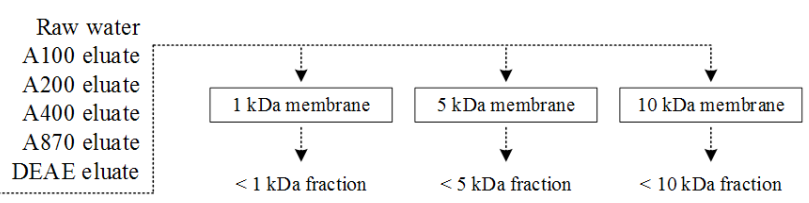

Figure 1. Fractionation scheme of humic substances.
$<1 \mathrm{kDa}, 1-5 \mathrm{kDa}, 5-10 \mathrm{kDa}$ and $>10 \mathrm{kDa}$. The $1-5 \mathrm{kDa}$ and $5-10 \mathrm{kDa}$ fractions were calculated as a difference of the appropriate indicator measured in $1 \mathrm{kDa}, 5 \mathrm{kDa}$ and $5 \mathrm{kDa}, 10 \mathrm{kDa}$ membrane permeates respectively. Membrane separation was conducted on a test bench equipped with a Millipore Amicon 8400 stirred cell (Figure 2). The transmembrane pressure was $0.1 \mathrm{MPa}$, while the membrane surface amounted to $45.3 \mathrm{~cm}^{2}$.

In order to determine the desorption and isolation efficiency of NOM, the DOC load in feed solution, treated water and eluate was calculated on the basis of the concentration of DOC. Desorption efficiency was calculated by dividing the DOC load in the eluate by the difference between the DOC load in the feed solution and treated water, while isolation efficiency was a quotient of DOC loads in the eluate and feed solution.

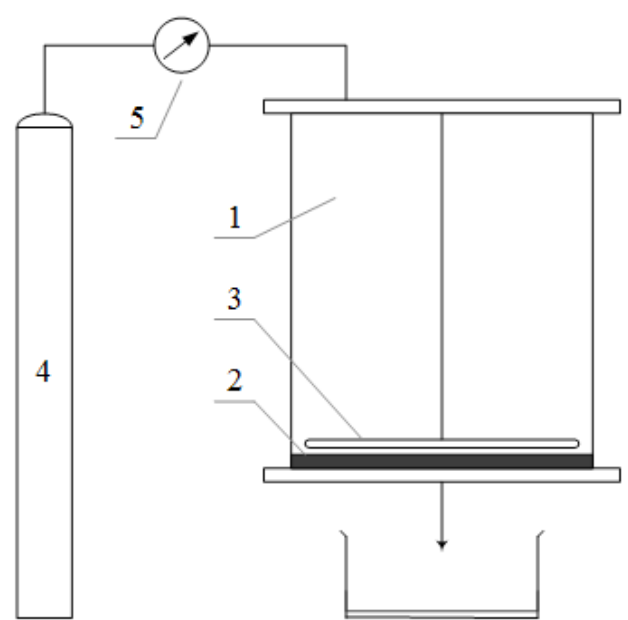

Figure 2. Membrane separation test bench with an Amicon 8400 stirred cell (1 - ultrafiltration cell, 2 membrane, 3 - stirrer, 4 - compressed nitrogen cylinder, 5 - pressure regulator).

\section{RESULTS AND DISCUSSION}

Among the technological processes used to remove humic substances from water, ion exchange with the use of anion-exchange resins is often applied. This research confirmed the high efficiency of this process. The final water quality was determined primarily by 
the type of ion-exchange resin used. Analysis of the obtained results (Figure 3) allowed the tested resins to be classified according to the exchange capacity of humic substances as follows: DEAE $>$ A $870>$ A100 $>$ A400 $>$ A200. The results of the study clearly show that, among the tested resins, DEAE cellulose was the most effective. For example, for model solution 1 , the use of this adsorbent resulted in a decrease in color intensity by about $96 \%$, UV $254 \mathrm{~nm}$ absorbance by $95 \%$ and DOC concentration by $88 \%$. Among the other ion exchange resins, A870 and A100 had the greater ion exchange capacity towards HS. This can be explained by the fact that the A870 resin is a mixed weak and strong base, while A100 is a weak base resin with a macroporous structure, which facilitates the penetration of NOM molecules and their retention in the anion-exchanger structure. For the A870 and A100 resins, HS isolation was mainly determined by the physical sorption mechanism. Moreover, it was observed that the ability to isolate HS depended on the moisture content of the ion exchange resin: resins containing more water in their structure, due to a more open structure, allowed for a better penetration of organic macromolecules, which can also fully explain the alignment of the anion exchange resins by exchange capacity. This is also consistent with other findings (Bolto et al., 2002b).
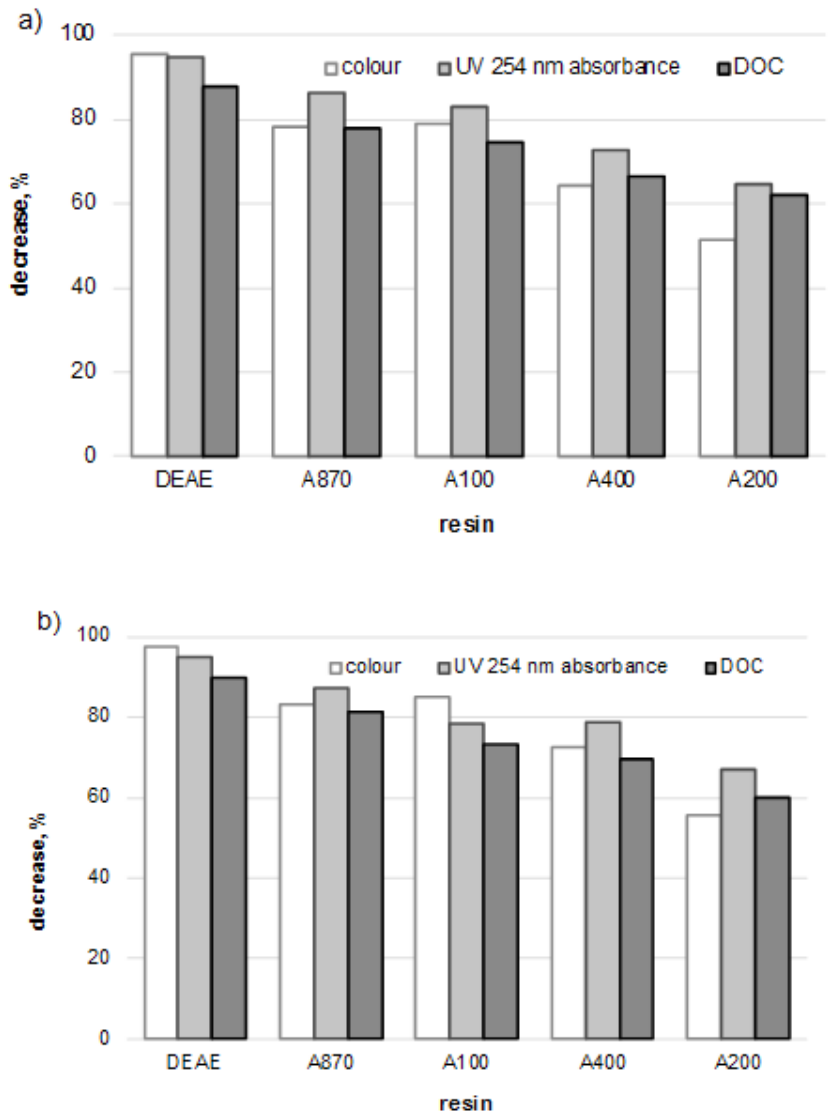

Figure 3. NOM removal efficiency from (a) model solution 1 and (b) model solution 2 .
In the next stage of the research, natural organic matter isolated with the use of several anion-exchange resins was the subject of fractionation with the use of ultrafiltration membranes. The studies to determine the molecular weight distribution for both raw model solutions and isolated NOM fractions are shown in Figures 4 and 5 .

a)

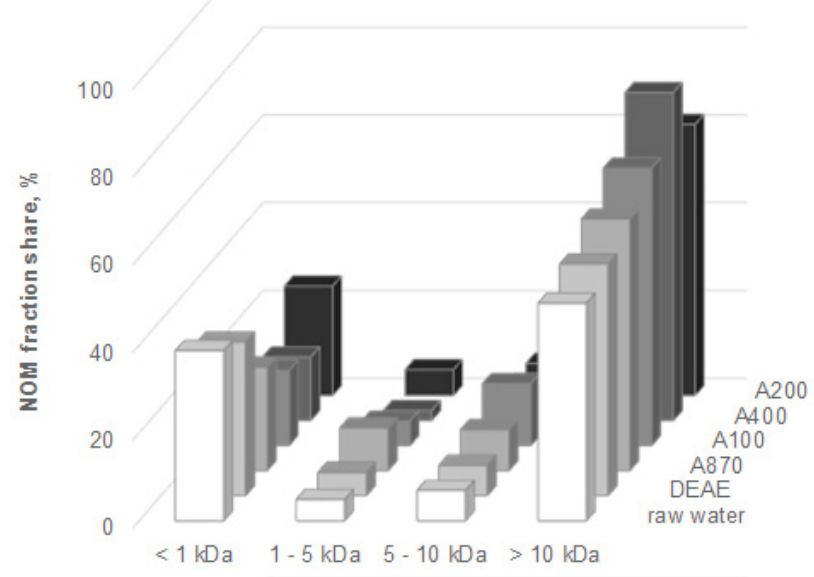

b)

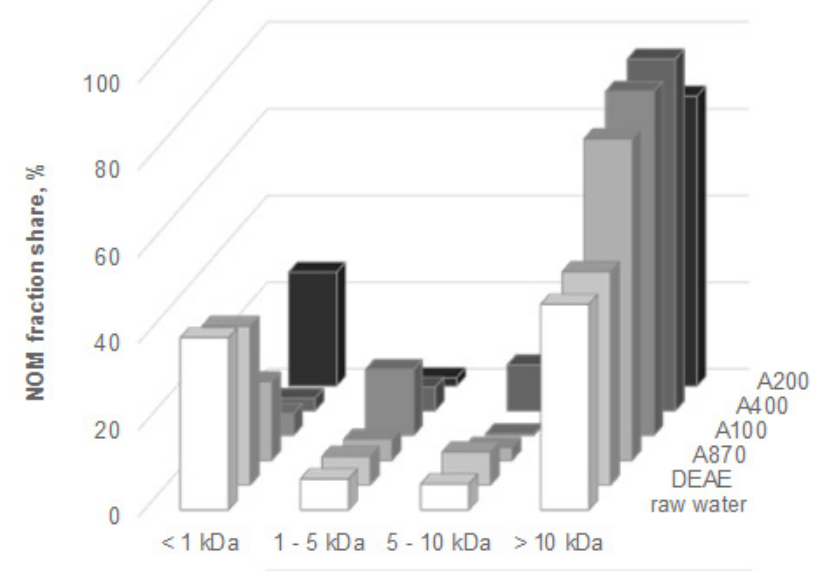

c)

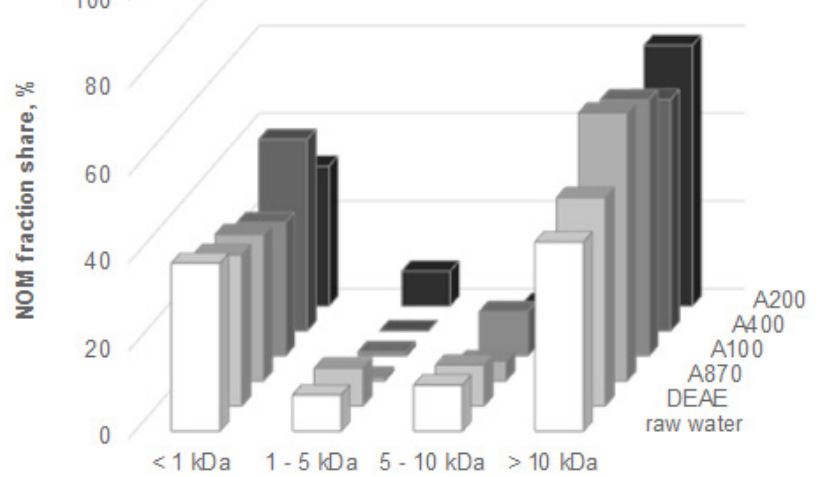

Figure 4. NOM fractions present in model solution 1 and ion exchange resin eluates $(\mathrm{a}-$ color intensity, $\mathrm{b}-$ UV $254 \mathrm{~nm}$ absorbance, $\mathrm{c}-$ DOC concentration). 
Analysis of the molecular size distribution of humic substances in the raw model solutions shows the importance of the type of feed solution. With model solution 1 being a mixture of natural and tap water after dechlorination, hydrophilic low molecular weight fractions predominated. In contrast, in model solution 2 with Aldrich humic acids, the vast
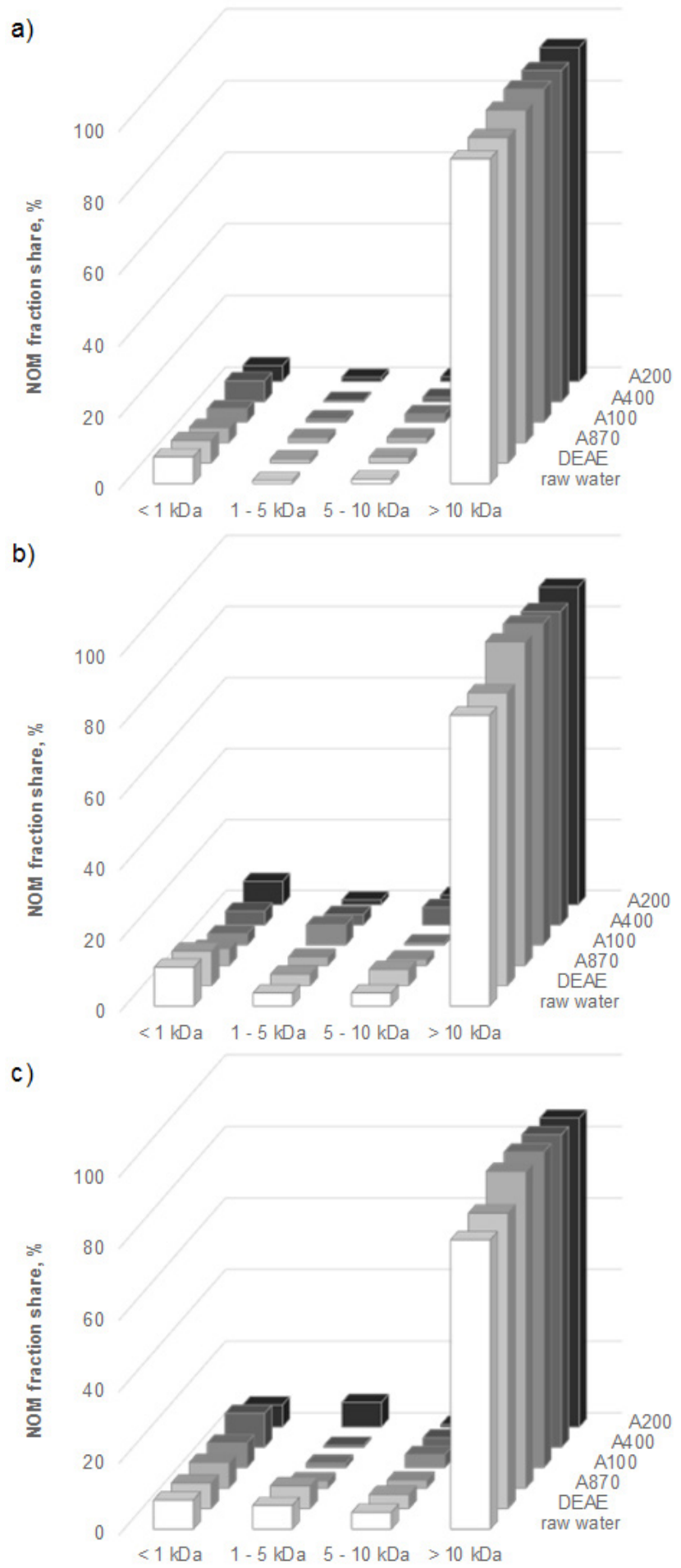

Figure 5. NOM fractions present in model solution 2 and ion exchange resin eluates ( $\mathrm{a}$ - color intensity, $\mathrm{b}-$ UV $254 \mathrm{~nm}$ absorbance, $\mathrm{c}-$ DOC concentration). majority of compounds were high molecular weight hydrophobic organic compounds. The contribution of the individual fractions determined on the basis of the DOC concentration was $<1 \mathrm{kDa} 38 \%, 1-5 \mathrm{kDa}$ $8 \%, 5-10 \mathrm{kDa} 11 \%$, and $43 \%$ for fractions $>10 \mathrm{kDa}$ for model solution 1 and $8 \%, 6 \%, 5 \%, 81 \%$ for model solution 2 , respectively. The dominant share of the fraction $>10 \mathrm{kDa}$ obtained for the Aldrich humic acids is in accordance with results presented by others (Lee et al., 2008).

Based on the results obtained for the anionic resin eluates, it was found that DEAE cellulose isolated each fraction to the same extent, which is in accordance with the literature (Lam and Simpson, 2006). For example, for model solution 1, the molecular weight distribution in the eluate after DEAE cellulose (based on: color; UV $254 \mathrm{~nm}$ absorbance; DOC measurements) was as follows: $35 \% ; 37 \% ; 34 \%$ for $<1 \mathrm{kDa}$ fraction, $5 \%$; 7\%; $9 \%$ for $1-5 \mathrm{kDa}, 7 \%$; $8 \%$; $9 \%$ for $5-10 \mathrm{kDa}$ and $53 \%$; $49 \%$; $48 \%$ for $>10 \mathrm{kDa}$. When analyzing the molecular weight distribution in the eluates after the ion exchange process for the rest of the evaluated resins, it was found that the isolation of compounds with high molecular weights $>10 \mathrm{kDa}$ could be primarily observed, while the isolation of the low molecular fractions was less effective. This observation is in accordance with literature reports (Bolto et al., 2002a). They found that Purolite resins mostly remove strong and weak hydrophobic acids (VHA and SHA), which are charged hydrophilic compounds (CHA) with a high molecular weight. To a lesser extent, Puroilie resins remove the small molecules of neutral hydrophilic compounds (NEU). For example, a decrease in the share of $<1 \mathrm{kDa}$ fraction from $38 \%$ to $30 \%$ and an increase in $>10 \mathrm{kDa}$ fraction content from $43 \%$ to $59 \%$ for model solution 1 in A100 eluate was observed (compared to raw water). In addition, no significant changes in the distribution of "intermediate" fractions ( $1-5 \mathrm{kDa}$ and $5-10 \mathrm{kDa})$ were noticed.

In the case of applying the ion-exchange process for the isolation of NOM particles from the water matrix, the efficiency of the elution/desorption and the isolation of macromolecules is crucial. The effectiveness of the desorption and isolation of organic macromolecules for both model solutions was also assessed (Figure 6) in this research.

Analysis of the HS desorption efficiency shows that $20 \%$ to $50 \%$ of DOC was not desorbed by $0.1 \mathrm{M}$ $\mathrm{NaOH}$ and each of the examined adsorbents required an additional purification. Furthermore, it was found that the desorption efficiency for model solution 2 was noticeably higher. This could have resulted from the easier desorption of the dominant high molecular 


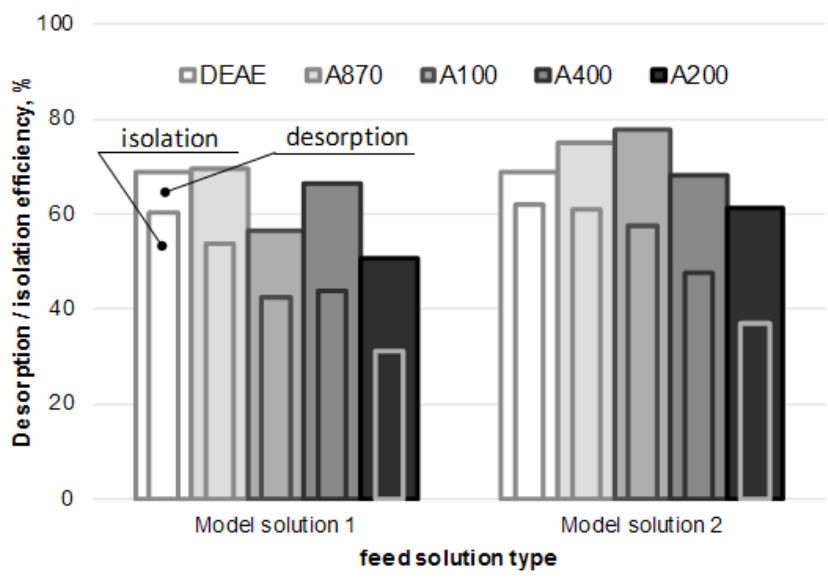

Figure 6. DOC desorption and isolation efficiency.

weight fraction in this solution. Among the analyzed resins, the highest desorption capacity was obtained for resin A100 (78\%) for model solution 2 and resin A870 (70\%) for model solution 1 . As both resins have a weak base character, we can surmise that the $0.1 \mathrm{M} \mathrm{NaOH}$ solution was effective in the desorption of physically adsorbed macromolecules. Thanks to the aforementioned high DOC removal efficiency by DEAE resin (Figure 3), it was also found that, despite lower desorption efficiency, DEAE resin was most effective in NOM isolation for both model solutions $(60 \%$ and $62 \%)$.

\section{CONCLUSIONS}

The research presented in this paper allowed for the following conclusions to be made:

- despite a similar concentration of organic substances in the solutions, there were substantial differences in the properties of humic substances: the natural water source was rich in hydrophilic low molecular weight compounds, while the humic acid solution was dominated by hydrophobic heavy molecular weight particles,

- the order of anion exchangers by humic acid substances adsorption efficiency was as follows: DEAE $>>$ A $870>$ A $100>$ A $400>$ A200,

- only DEAE resin was able to isolate each fraction to the same extent, while other exchangers isolated larger compounds more preferably,

- none of the anion exchangers enabled the total desorption of humic substances and further regeneration is required to restore their initial capacity.

\section{ACKNOWLEDGEMENTS}

The work was partially financed from funds allocated for statutory research of the Faculty of
Environmental Engineering, Wroclaw University of Science and Technology (Order No 0401/0064/16).

\section{REFERENCES}

Baalousha, M., Manciulea, A., Cumberland, S., Kendall, K. and Lead, J.R., Aggregation and surface properties of iron oxide nanoparticles: Influence of ph and natural organic matter. Environ Toxicol Chem, 27, 1875-1882 (2008).

Bolto, B., Dixon, D., Eldridge, R. and King, S., Removal of THM precursors by coagulation or ion exchange. Water Res, 36, 5066-5073 (2002a).

Bolto, B., Dixon, D., Eldridge, R., King, W. and Linge, K. Removal of natural organic matter by ion exchange. Water Res, 36, 5057-5065 (2002b).

Bond T., Templeton M.R., Rifai O., Ali H., and Graham N.J.D., Chlorinated and nitrogenous disinfection by product formation from ozonation and postchlorination of natural organic matter surrogates. Chemosphere, 111, 218-224 (2014).

Boyer, T.H., Singer, P.C. and Aiken, G.R., Removal of dissolved organic matter by anion exchange: Effect of dissolved organic matter properties. Environ Sci Technol, 42, 7431-7437 (2008).

Cornelissen, E.R., Moreau, N., Siegers, W.G.,Abrahamse, A.J., Rietveld, L.C. Grefte, A., Dignum, M., Amy, G. and Wessels, L.P., Selection of anionic exchange resins for removal of natural organic matter (NOM) fractions. Water Res, 42, 413-423 (2008).

Grefte, A., Dignum, M., Cornelissen, E.R., and Rietveld, L., Natural organic matter removal by ion exchange at different positions in the drinking water treatment lane, Drink Water Eng Sci, 6, 1-10 (2013).

Honokis, J., Valero-Freitag, S., Caporgno, M.P. and Patzold, C., Removal of nitrate and fluoride by nanofiltration - a comparative study. Desalin Water Treat, 30, 278-288 (2011).

Krupińska, I., Kowalczyk, W. and Szczepaniak, G., Wpływ wartości współczynnika współwystępowania substancji organicznych i żelaza ogólnego w wodzie podziemnej na skuteczność jej oczyszczania (in Polish). Ochrona Środowiska, 35, 27-34 (2013).

Lam, B. and Simpson, A.J., Passive sampler for dissolved organic matter in freshwater environments. Anal Chem, 78, 8194-8199 (2006).

Lee, H.H., Weng, Y.H. and Li, K.C., Electroultrafiltration study on Aldrich humic substances with different molecular weights. Sep Purif Technol, 63, 23-29 (2008).

Maeng, S.K., Timmes, T.C. and Kim, H.C., Characterization of EfOM fraction responsible for short-term fouling in ultrafiltration. Sep Sci Technol, 50, 2697-2707 (2015). 
Malaisamy, R., Talla-Nwafo, A. and Jones, K., Polyelectrolyte modification of nanofiltration membrane for selective removal of monovalent anions. Sep Purif Technol, 77, 367-374 (2011).

Metsämuuronen, W., Sillanpää, M., Bhatnagar, A. and Mänttäri, M., Natural organic matter removal from drinking water by membrane technology. Sep Purif Rev, 43, 1-61 (2014).

Microdyn Nadir, http://www.microdyn-nadir.com/ fileadmin/user_upload/downloads/catalogue.pdf.

Nieder, R. and Benbi, D.K., Carbon and Nitrogen in the Terrestrial Environment. Berlin, Germany (2008).

Pruss, A. and Pruss, P., An attempt at application of powdered activated carbon and selective anionite to increase effectiveness of organic matter elimination from water after coagulation process (in Polish). Ochrona Środowiska, 38, 25-28 (2016).

Purolite, http://www.aquatech.ro/wp-content/ uploads/2012/06/Catalog-PUROLITE.pdf.

Rajca, M., Impact of the water composition on the degradation kinetics of natural organic matter in photocatalytic membrane reactors. Environ Prot Eng, 41, 29-39 (2015).

Santa Cruz Biotechnology, https://www.scbt.com/ scbt/product/deae-cellulose-9013-34-7.

Sillanpää, A.M., Natural Organic Matter in Water: Characterization and Treatment Methods, ButterworthHeinemann, London, Great Britain (2014).
Steinberg, C.E.W., Ecology of Humic Substances in Freshwaters. Berlin, Germany (2003).

Sutzkover-Gutman, I., Hasson, D., and Semiat, R., Humic substances fouling in ultrafiltration processes. Desalination, 261, 218-231 (2010).

Tan, Y., Humic Matter in Soil and the Environment: Principles and Controversies, CRC Press, Boca Raton, USA (2014).

Tubić A., Agbaba J., Dalmacija B., Molnar J., Maletić S., Watson M., and Perović S.U., Insight into changes during coagulation in NOM reactivity for trihalomethanes and haloacetic acids formation. $\mathrm{J}$ Environ Manag, 118, 153-160 (2013).

Wershaw, R.L., Kennedy, K.R. and Henrich, J.E., Use of 13C NMR and FTIR for elucidation of degradation pathways during natural litter decomposition and composting. IV. Characterization of humic and fulvic acids extracted from senescent leaves. In: Davies G, Ghabbour EA (eds) Humic Substances. Structures, Properties and Uses, Cambridge, 29-46 (1998).

Zazouli, M.A., Nasseri, S., Mahvi, A.H., Gholami, M., Mesdaghinia, A.R. and Younesian, M., Retention of humic acid from water by nanofiltration membrane and influence of solution chemistry on membrane performance. J Environ Health Sci Eng, 5, 11-18 (2008). 
